\title{
PERCEPTION AND OPTIMISM ABOUT TWO-SEMESTER OFF-CAMPUS INTERNSHIP PROGRAM OF THE POLICY OF KAMPUS MERDEKA-MERDEKA BELAJAR AMONG UNIVERSITY STUDENTS
}

\author{
${ }^{1}$ Lalu Jaswadi Putera, ${ }^{2}$ Riris Sugianto \\ ${ }^{1}$ English Lecturer, Faculty of Teacher Training and Education, Mataram University, Indonesia \\ ${ }^{2}$ English Lecturer, Mataram University of Technology, Indonesia \\ Corresponding Author Email: lalujaswadi1981@gmail
}

\begin{tabular}{ll}
\hline \hline Article Info & Abstract \\
\hline Article History & The Education and Culture Ministry of Indonesia has just launched a newly- \\
Received: June 2020 & reformed national education system called the "Merdeka Belajar-Kampus \\
Revised: July 2020 & Merdeka" (Freedom Campus-Freedom to Learn)" policy. One of the four \\
Published: July 2020 & hallmarks of the Merdeka Belajar-Kampus Merdeka policy is the three-semester \\
Keywords & off-campus internship program for university students. Despite the supports, \\
Off-campus internship & there is still debate as to whether the program will be effective and pro-students \\
program; & when implemented. Apart from the policy's pros and cons, the program needs to \\
Merdeka belajarpolicy; $;$ & be objectively understood not only from the government's and academics' \\
Freedom Campus; & perspectives but also from the students whose voice is time and again \\
& marginalized when a new policy is being planned, drafted, and implemented. \\
& Besides, there are still limited studies that deal with this issue. Therefore, further \\
studies need to be conducted. This study investigates the students'perception and & optimism toward the off-campus internship program of the Kampus Merdeka- \\
Merdeka Belajar policy. The probing questions about perceptions were related to \\
whether the program was satisfactory, overwhelming, inflicting, or simply \\
industry-oriented instead of student-oriented according to the students. The \\
probing questions about optimism were related to whether the students were \\
optimistic that the program would bring improvement to their knowledge, skills, \\
and pre-working experiences. Data were collected from 229 2nd and 4th- \\
semester students across departments in Mataram University by conducting an \\
online questionnaire. Results show that the students had a positive perception of \\
the off-campus internship program (49\%) and they were very optimistic that this \\
program would be effective when implemented (71\%).
\end{tabular}

How to cite: Putera, L. J., \& Sugianto, R. (2020). Perception and optimism about two-semester off-campus internship program of the policy of kampus merdeka-merdeka belajar among university students. JOLLT Journal Languages and Language Teaching, 8(3), 264-275, DOI: https://doi.org/10.33394/jollt.v\%vi\%i.2756

\section{INTRODUCTION}

The Ministry of Education and Culture of the Republic of Indonesia has just reformed the national education system with a new direction policy called the "Merdeka Belajar" or Freedom To Learn policy. This policy was issued in 2 (two) stages. Stage 1 was the Merdeka Belajar 1 policy for primary and secondary education (Kemendikbud, 11/12/2019) and stage 2 was the Merdeka Belajar 2 policy for higher education (Kemendikbud, 24/01/2020). The Merdeka Belajar 1 policy - which is for the primary and secondary education - has four main programs that include reforming the National Standard School Examination (USBN), National Examination (UN), Lesson Plan (RPP), and Zoning Regulations for New Student Enrollment (PPDB). Meanwhile, the Merdeka Belajar 2 policy or better known as the 
"Kampus Merdeka" (Freedom Campus) has also four main programs that include the opening of new study programs, reformed higher education accreditation systems, state-owned tertiary institutions, and three-semester off-campus internship program or known as "magang" for university students (Ministry of Education and Culture, 01/24/2020).

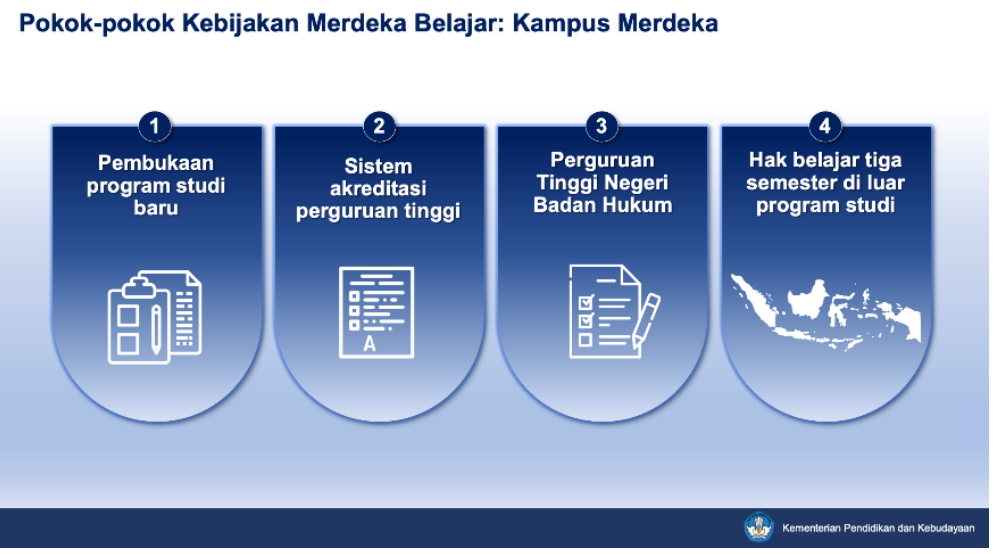

Figure 1. The Four Principles of Merdeka Belajar: Kampus Merdeka Policy

(Source: www.kemdikbud.go.id)

Speaking of the Kampus Merdeka policy, several reports indicate that there are a lot of supports from the universities and academics such as those from UGM academics claiming to be ready to contribute and hoped to be in the frontline (Tempo, 01/26/2020). In line with UGM, academics at UI and ITB also positively welcomed this policy (Tempo, 01/26/2020). Despite receiving a lot of support, the program has also drawn criticism from several academics and student union executives. The Chairperson of the University of Indonesia's Student Executive Board (BEM) criticizes the time given to make an adjustment to this new policy is too short. He also prejudices that this policy is promoting "modern slavery" by utilizing students as cheap workers (Rational Media, 02/18/2020). Other critics argue that this policy favors the industries for their own profit. Prabowo (29/01/2020) argues that this policy does not endorse education as a true education that carves and shapes students to become philosophers and innovators. Rather, it reinforces a form of commercialization of education that positions teachers and students as part of the market industry (Hemlata \& Sharma, 2019:1266; Borgohain, 2016:71; Richards et al, 1988:149).

Apart from the policy's pros and cons, the program needs to be objectively seen not only from the government's and the academics' points of view but also from the students' whose voice is time and again unheard when a new policy is being planned, drafted, and implemented. Besides, there are still limited studies that deal with this issue. Therefore, it is necessary to conduct further studies as to how the students perceive the Kampus MerdekaMerdeka Belajar policy and how optimistic they are towards it. In order to identify how students perceive this policy and how optimistic they are concerning the effectiveness of this policy, the researcher put them into two categories: the perception and the optimism categories. The probing questions in the perception category were related to whether the program was satisfactory, overwhelming, inflicting for the students, or simply industryoriented instead of student-oriented. Meanwhile, the probing questions in the optimism category were related to the students' optimism as to whether the program could improve their knowledge, skills, and pre-working experiences.

\section{The Concept of Merdeka Belajar}

According to the Kemendikbud's Director General of Higher Education (Kemendikbud, 2020), the new concept of the Kampus Merdeka redefines the meaning of school and learning 
from what was originally only a narrow and limited space to become more widespread and deeper meaning. School and learning no longer always have to be inside the classroom building or on-campus but can also be off-campus. In addition to that, the Head of the Communication and Community Services Bureau of the Education and Culture Ministry stated that the philosophy of the Freedom to Learn policy is how to create a fun and happy learning environment for students, teachers, the community, and all the people. Merdeka or free in terms of freedom from rules that limit the space for the students to create and develop themselves (Media Indonesia, 18/12/2019).

The concept of Merdeka Belajar itself is not a new concept (Mustaghfiroh, 2020:141). It is connected with the progressivism theory put forward by John Dewey who longed for a fundamental change in the implementation of education to achieve quality and benefit for students. He emphasized the importance of the foundation of "independence learning" for students to explore their hidden talents and abilities. This concept later came to be known as constructivism theory which focused more on education for the community (Dewey, 1920; Ornstein, 2018; Watson \& Coso, 2013 in Nugroho, 2013 in Nugroho \& Purwanta, 2020:133; Dewey in Dasein 2018:61-69).

The concept of Freedom to Learn had also been coined by the Father of Indonesian Education, Ki Hajar Dewantara, as outlined in his two books titled Bagian Pertama: Pendidikan (Dewantara, 2004) and Menjadi Manusia Merdeka (Dewantara, 2009) where the desired goal was to establish human beings who are independent and free from the enslavement of other human beings. In his opinion, education - in its real sense - is the process of humanizing humans (Dewantara, 2009:3 in Mujito, 2014:69). So, the concept of Merdeka Belajar is fundamentally a noble concept that was tailored and grown by a noble conceptor throughout the epic struggle for our national independence.

UNICEF highlights education as fundamental for humans that all of us have a right to learn. "We are entitled to an effective learning environment in multiple spaces, not just the school setting and at the primary level. All people are entitled to express their views and have them given due weight." (UNICEF, 2007:36). People have right to enjoy their own culture, practice their own religion, use their own language, and gain an education that is free from fear, boundaries, and discrimination. The concept of Merdeka Belajar is in line with this international human rights convention that affirms everybody must be given the freedom to education and let them experience the process of excerpting education in the happiest and most motivating way. Osman (2013, p.144) quotes Hook (1974) who states that a democratic society whose moral premise is that each individual has a right to an education that will permit him to achieve his maximum growth as a person, therefore, everyone's duty is to work for or support to remove the social obstacle to freedom of learning.

In addition, the psychological theory of learning also supports the idea that learning through free play and exploration is good for psychological development, through those means we acquired skills, values, ideas, and information that will stay with us for life, not just for the next test. And, perhaps most importantly, we discovered what we most enjoy, which is the first step in finding a satisfying career." (Gray, 2011:1).

\section{The Effectiveness of Internship Programs}

Several studies have reported the success in implementing the internship programs. Commonly, many studies have revealed that students who had the experience in doing the internship programs realize the advantages and benefits they get. Basically, both students and the companies/industries found the program effective and mutual.

The first previous study conducted by Muslih (2014) investigated the effectiveness of an internship program between the students of Muhammadiyah University majoring in Management of Economics studies and RS. Muhammadiyah hospital, RS Haji Hospital, and 
PT Perkebunan Nusantara in North Sumatera. The results showed that both students and companies found the program effective. In the second study, conducted by Wijaya (2019) investigating the effectiveness of a certified internship program in several state-owned companies such as PT INKA, PTPN X, PTPN XI, PELINDO III, PT PAL, PETROKIMIA GRESIK, PT SIER, dan PT SURVEYOR INDONESIA in Kalimantan. The participants were students of Hang Tuah University majoring in Psychology, Business Administration, and Electrical Engineering departments from three different backgrounds: active students, unemployed graduated students and employed graduate students. The results showed that the program was effective in improving students' working skills and work ethics.

In the third study conducted by Wirawan et al (2017), it investigated the motivation of students majoring in Tourism in Bali to take a job practice training conducted in the USA. The motivation was concerned with factors such as knowledge, skill, self-concept/value, personal characteristic, and motives. The results showed that the students were so motivated to take an internship program and argued that job training in the US would provide excellent benefits in terms of knowledge, skills, self-concept, personal characteristic, and motive.

In the fourth study conducted by Nofiani and Julianto (2018), investigating the effectiveness of the implementation of internship program toward the capability of TPACK (Technological Pedagogical Content Knowledge) among prospective Biology teachers who had taken Batch 1, 2, and 3 of the internship program at FKIP Muhammadiyah University in Purwokerto. The results showed that the students considered the internship program was effective.

\section{RESEARCH METHOD}

\section{Research Design}

In this study, the qualitative method which utilized questionnaire was used, since this study focused on the perceptions and optimism that were directly collected from the respondents. At the initial phase of the research, participants were given a brief explanation about what Kampus Merdeka and Merdeka Belajar policy were and what were the concept and philosophy behind it. This phase lasted about 20-30 minutes right after the class was over. Students were allowed to ask questions. After that, students were asked to read more information about this policy from other relevant resources such as the official Kemendikbud website and leading online newspapers like The Jakarta Post, Kompas, and many others. At the second phase of the research, the researcher collected, drafted, and sorted questions relevant to the research scope and objectives. The researcher then designed a questionnaire and distributed it to the students or the participants via class Whatsapp groups. At the final phase, data were analyzed and divided into several categories to meet the research objectives. Finally, the findings were discussed and conclusions were drawn to ascertain that this study had achieved the objectives.

\section{Population and Sample}

The target samples of this study were all 2nd and 4th-semester students from different faculties at Mataram University. The samples were selected based on the researcher's preference that all students were taking courses managed by the researcher himself during the semester since, first, it would make it easier for the researcher to socialize the Kampus Merdeka-Merdeka Belajar policy to the students in class and instruct them to read more information about the policy from other relevant sources after class; and second, easier for the researcher to coordinate with all participants during data collection phase since both researcher and students used to see each other during the weekly class. 
Of the total samples, 229 respondents submitted the questionnaire. The submission lasted for about 1 month starting from the 1st of February 2020 to the 1st of March 2020.

\section{Instruments}

This study used an online questionnaire as a data collection instrument. The questionnaire was created by using Google Forms that comprised 8 (eight) question items divided into two question categories, those are, the perception category with 4 questions and the optimism category with 4 questions as well.

The perception category would answer the questions about the students' perceptions of the off-campus internship program of the Kampus Merdeka-Merdeka Belajar policy. In this category, the probing questions were related to whether the program was satisfactory (Q1), overwhelming (Q2), inflicting to the students (Q3), or simply industry-oriented instead of student-oriented one (Q4) (See Table 1 below).

Table 1.

Perception Questions Category

\begin{tabular}{cl}
\hline No & Perception Questions \\
\hline 1 & Menurut anda, apakah program magang dua semester di luar kampus ini bagus bagi mahasiswa? \\
& Is the two-semester off-campus internship program satisfying for students? \\
\hline 2 & $\begin{array}{l}\text { Menurut anda, apakah program magang dua semester di luar kampus ini membebani mahasiswa? } \\
\text { In your opinion, is the two-semester off-campus internship program overwhelming to students? }\end{array}$ \\
\hline 3 & $\begin{array}{l}\text { Menurut anda, apakah program magang dua semester di luar kampus merugikan mahasiswa? } \\
\text { In your opinion, is the two-semester off-campus internship program inflicting for students? }\end{array}$ \\
\hline 4 & $\begin{array}{l}\text { Menurut anda, apakah program magang dua semester di luar kampus hanya menguntungkan } \\
\text { perusahaan/industri? } \\
\text { In your opinion, does the two-semester off-campus internship program only benefit companies/industry? }\end{array}$ \\
\hline
\end{tabular}

Meanwhile, the optimism category would seek to answer questions about the students' optimism on the effectiveness of the off-campus internship program of Kampus MerdekaMerdeka Belajar policy. In this category, the probing questions were related to whether the students were optimistic that the program would make an improvement in their knowledge (Q1), skills, and pre-working experiences (Q2). In addition, it asked the students as to whether they were optimistic that the quality of our national education would improve under the new minister with his Kampus Merdeka-Merdeka Belajar policy (Q3); and whether they were optimistic the two-semester off-campus internship program would greatly contribute to the drop in the undergraduate unemployment rate (Q4) (See Table 2 below).

Table 2.

Optimism Questions Category

\begin{tabular}{cl}
\hline No & Optimism Questions \\
\hline $1 \quad$ & Apakah anda optimis program magang dua semester di luar kampus dapat meningkatkan keilmuan \\
& mahasiswa? \\
& How optimistic are you that the two-semester off-campus internship program will improve students' \\
knowledge? & Apakah anda optimis program magang dua semester di luar kampus ini dapat meningkatkan keterampilan \\
& dan pengalaman pra-kerja mahasiswa? \\
& How optimistic are you that the two-semester off-campus internship program will improve students' skills \\
& and pre-working experiences? \\
\hline 3 & Apakah anda optimis kualitas pendidikan nasional dapat meningkat di bawah kepemimpinan menteri \\
& muda dengan program Merdeka Belajar? \\
& How optimistic are you that the quality of our national education will improve under a new minister with \\
& his Merdeka Belajar policy? \\
\hline 4 & Apakah anda optimis program magang dua semester di luar kampus dapat mengurangi jumlah \\
& pengangguran sarjana di Indonesia 5-10 tahun ke depan?
\end{tabular}


How optimistic are you that the two-semester off-campus internship program will contribute to the decrease of the undergraduate unemployment rate?

For the questionnaire responses, 5-option Likert Scale was provided in each question. The 5 scales in the perception category ranged from 1-Strongly Agree, 2-Agree, 3-Neutral, 4Disagree, and 5-Strongly Disagree (See Table 3 below).

Table 3.

Likert Scale options in Perception Category

\begin{tabular}{cl} 
No & Options \\
\hline 1 & Strongly Agree \\
\hline 2 & Agree \\
\hline 3 & Neutral \\
\hline 4 & Disagree \\
\hline 5 & Strongly Disagree
\end{tabular}

While the 5 scales in the optimism category ranged from 1-Very Optimistic, 2Optimistic, 3-Neutral, 4-Pessimistic, and 5-Very Pessimistic (See Table 4 below).

Table 4.

Likert Scale options in Optimism Category

\begin{tabular}{cl} 
No & Options \\
\hline 1 & Very Optimistic \\
\hline 2 & Optimistic \\
\hline 3 & Neutral \\
\hline 4 & Pessimistic \\
\hline 5 & Very Pessimistic
\end{tabular}

\section{Data Collection}

This study used Google Forms spreadsheet (GF) to create a questionnaire, distribute it to the participants for data collection, and graph data for analysis. GF was used in order for the researcher to collect data immediately and analyze the results with ease since GF presents or displays real-time data (RTD). The GF questionnaire was then distributed to each class via the Whatsapp group. To maintain the confidentiality of the survey results, the questionnaire did not request any personal information such as the respondent's name and identification number. The "Limit to 1 Response" feature was activated to let only 1 respondent using 1 device (OROD = One Respondent One Device) be able to fill in the questionnaire. To check the validity of the study, the researcher provides a link address to the survey at https://bit.ly/2PersepsiMerdekaBelajar.

Kindly notice that prior to data collection, the researcher socialized the topic about the off-campus internship program, Kampus Merdeka, and Merdeka Belajar policy to the students 20-25 minutes before/after class. He also assigned them to read more information from relevant offline and online sources such as Kemendikbud.go.id, Kompas, or The Jakarta Post, in order to get them accustomed to the topic, would be asked in the questionnaire.

\section{Data Analysis}

The data were analyzed using qualitative data analysis. For the frequency of responses in the questionnaire, the statistical data were not analyzed manually by the researcher but calculated and displayed automatically by GF in real-time data (RTD) based on each question and criterion (1-Strongly Agree, 2-Agree, 3-Neutral, 4-Disagree, and 5-Strongly Disagree) for perception category and (1-Very Optimistic, 2-Optimistic, 3-Neutral, 4-Pessimistic, and 5Very Pessimistic) for optimism category. The researcher took the statistic data and presented them in the Findings and Discussion section. Finally, the researcher calculated and interpreted the given statistic data into qualitative data based on the two categories (1-Strongly Agree, 2- 
Agree, 3-Neutral, 4-Disagree, and 5-Strongly Disagree) for perception category and (1-Very Optimistic, 2-Optimistic, 3-Neutral, 4-Pessimistic, and 5-Very Pessimistic) for optimism category. In the perception category, the statistic data were interpreted into three criteria: positive perception, neutral perception, and negative perception. In the optimism category, the statistic data were interpreted into three criteria: optimistic, neutral, and pessimistic.

\section{RESEARCH FINDINGS AND DISCUSSION}

\section{Research Findings}

This section presents scores for questions on perception and optimism about the offcampus internship program of the Kampus Merdeka-Merdeka Belajar policy among students. The data presentation is begun with the scores of perception questions (as shown in Table 5) and ended with the score of optimism questions (as shown in Table 6).

Table 5

Scores of Perception Questions No. 1-4

Note: QP = Perception Questions

\begin{tabular}{|c|c|c|c|c|c|c|c|c|c|}
\hline & \multirow{2}{*}{ Criteria } & \multicolumn{2}{|c|}{ QP-1 } & \multicolumn{2}{|c|}{ QP-2 } & \multicolumn{2}{|c|}{ QP-3 } & \multicolumn{2}{|c|}{ QP-4 } \\
\hline & & Freq. & $\%$ & Freq. & $\%$ & Freq. & $\%$ & Freq. & $\%$ \\
\hline \multirow{3}{*}{$\begin{array}{l}\text { Positive } \\
\text { Perception }\end{array}$} & Strongly Agree & 42 & 18.3 & 10 & 4.4 & 4 & 1.7 & 6 & 2.6 \\
\hline & Agree & 98 & 42.8 & 49 & 21.4 & 8 & 3.5 & 15 & 6.6 \\
\hline & Subtotal & 140 & 61.1 & 59 & 25.8 & 12 & 5.2 & 21 & 9.2 \\
\hline \multirow{2}{*}{$\begin{array}{c}\text { Neutral } \\
\text { Perception }\end{array}$} & Neutral & 72 & 31.4 & 107 & 46.7 & 84 & 36.7 & 95 & 41.5 \\
\hline & Subtotal & 72 & 31.4 & 107 & 46.7 & 84 & 36.7 & 95 & 41.5 \\
\hline \multirow{4}{*}{$\begin{array}{l}\text { Negative } \\
\text { Perception }\end{array}$} & Disagree & 13 & 5.7 & 58 & 25.3 & 112 & 48.9 & 102 & 44.5 \\
\hline & Strongly Disagree & 4 & 1.7 & 5 & 2.2 & 21 & 9.2 & 11 & 4.8 \\
\hline & Subtotal & 17 & 7.4 & 63 & 27.5 & 133 & 58.1 & 113 & 49.3 \\
\hline & Total & 229 & 100.0 & 229 & 100.0 & 229 & 100.0 & 229 & 100.0 \\
\hline
\end{tabular}

QP-1 in Table 5 shows the percentage of respondents' answers to perception question No 1 "Is the two-semester off-campus internship program satisfying for students?" in terms of whether the program would be good according to students. The score shows that the majority of respondents $(61.1 \%)$ thought that the off-campus internship program was "satisfying". Only $7.5 \%$ who thought it was "not satisfying".

QP-2 in Table 5 shows the percentage of respondents' answers to perception question No 2 "Is the two-semester off-campus internship program overwhelming for students?" in terms of whether this internship program would add to the learning burden for students. The results showed that $27.5 \%$ of respondents thought this internship program "did not add to their learning burden". This number is almost the same as the number of respondents who considered this program would give them more work to accomplish (25.8\%). While the number of respondents who were neutral scored the highest of the three by $46.7 \%$. The almost equal number of respondents who felt "overwhelmed" vs. "not overwhelmed" seemed to be caused by an incomplete picture of the total credits students would take when the program began as can be seen from the high percentage of neutral answers the participants took.

QP-3 in Table 5 shows the percentage of respondents' answers to the perception question No 3 "Is the two-semester off-campus internship program inflicting for students?" in terms of whether the off-campus internship program would be detrimental or inflicting to students both physically, psychologically, and financially. The survey results show that the majority of respondents $(58.1 \%)$ answered this apprenticeship program "is not inflicting" to them. Only a very insignificant number who considered the program "is detrimental" to the students $(5.2 \%)$. 
QP-4 in Table 5 shows the percentage of respondents' answers to the question of whether the off-campus internship policy would only benefit companies or industries instead of the students themselves. This question is related to the claim that this policy is so industryoriented rather than the student- or education-oriented. The claim that argued that the program would create university graduates as cheap workers rather than innovators or job creators. The survey results showed that $49.3 \%$ of respondents "disagreed" with the claim, while only a very insignificant number who considered the program only benefited companies or industries $(9.2 \%)$. The number of neutral respondents was almost as much as the agreed ones that is by $46.7 \%$.

Table 6

Optimism Questions No. 1-4

Note: QO = Optimism Question

\begin{tabular}{cccccccccc}
\multirow{2}{*}{ Criteria } & \multicolumn{2}{c}{ QO-1 } & \multicolumn{2}{c}{ QO-2 } & \multicolumn{2}{c}{ QO-3 } & \multicolumn{2}{c}{ QO-4 } \\
\cline { 2 - 10 } & & Freq. & \% & Freq. & \% & Freq. & \% & Freq. & \% \\
\hline \multirow{3}{*}{ Optimistic } & Very Optimistic & 62 & 27.1 & 86 & 37.6 & 40 & 17.5 & 15 & 6.6 \\
\cline { 2 - 10 } & Optimistic & 124 & 54.1 & 106 & 46.3 & 102 & 44.5 & 120 & 52.4 \\
\cline { 2 - 10 } Subtotal & $\mathbf{1 8 6}$ & $\mathbf{8 1 . 2}$ & $\mathbf{1 9 2}$ & $\mathbf{8 3 . 9}$ & $\mathbf{1 4 2}$ & $\mathbf{6 2}$ & $\mathbf{1 3 5}$ & $\mathbf{5 9}$ \\
\hline \multirow{2}{*}{ Neutral } & Sutral & 35 & 15.3 & 31 & 13.5 & 64 & 27.9 & 58 & 25.3 \\
\cline { 2 - 10 } & Subtotal & $\mathbf{3 5}$ & $\mathbf{1 5 . 3}$ & $\mathbf{3 1}$ & $\mathbf{1 3 . 5}$ & $\mathbf{6 4}$ & $\mathbf{2 7 . 9}$ & $\mathbf{5 8}$ & $\mathbf{2 5 . 3}$ \\
\hline \multirow{3}{*}{ Pessimistic } & Pessimistic & 6 & 2.6 & 4 & 1.7 & 8 & 3.5 & 21 & 9.2 \\
\cline { 2 - 9 } & Very Pessimistic & 2 & 0.9 & 2 & 0.9 & 15 & 6.6 & 15 & 6.6 \\
\cline { 2 - 10 } & Subtotal & $\mathbf{8}$ & $\mathbf{3 . 5}$ & $\mathbf{6}$ & $\mathbf{2 . 6}$ & $\mathbf{2 3}$ & $\mathbf{1 0 . 1}$ & $\mathbf{3 6}$ & $\mathbf{1 5 . 8}$ \\
\hline \multicolumn{2}{r}{ Total } & 229 & 100.0 & 229 & 100.0 & 229 & 100.0 & 229 & 100.0
\end{tabular}

QO-1 in Table 6 shows the percentage of students' answers to optimism question No 1 in terms of whether the students were optimistic that the off-campus internship program could improve students' knowledge. The survey results showed that respondents had very high optimism at $81.2 \%$ that the apprenticeship program would be "able to improve their knowledge". Insignificantly, 3.5\% of respondents thought that their understanding gained would not improve through this program.

QO-2 in Table 6 shows the percentage of answers to optimism question No 2 as to whether students were optimistic that this off-campus internship program could improve their skills and pre-working experiences. The survey results showed respondents had very high optimism by $83.9 \%$ that the internship program could "improve the skills and pre-working experiences" required by students. Only $2.6 \%$ of respondents were pessimistic about this program.

QO-3 in Table 6 shows the percentage of answers to optimism question No 3 as to whether the students were optimistic that the quality of Indonesian education would improve through this program under the administration of the new Minister of Education and Culture of, Nadiem Anwar Makarim. The survey results showed that respondents had high optimism at $62 \%$ that this program would succeed. $28 \%$ had a neutral position and only $10 \%$ of respondents were pessimistic about the success of this program under his leadership.

QO-4 in Table 6 shows the percentage of answers to optimism questions as to whether the students were optimistic about the program would be effective in cutting the undergraduate unemployment rate within the next 10-15 years. The survey results showed that $59 \%$ of respondents were optimistic that this program could cut the unemployment rate among university graduates. Only $15.8 \%$ of respondents thought that this program would fail to cut undergraduate unemployment rate among university students in Indonesia. 


\section{Discussion}

This section discusses the answers of the two questions stated previously in the Introduction section, those questions asked about the students' perception concerning the offcampus internship program of the Kampus Merdeka-Merdeka Belajar policy of the Ministry of Education and Culture of the Republic of Indonesia, and the level of optimism among students concerning the off-campus internship program of the Kampus Merdeka-Merdeka Belajar policy of the Ministry of Education and Culture of the Republic of Indonesia. Figures 2 and 3 show the summary scores of each question category (Perception and Optimism) complete with its variables.

Perception about Off-Campus Internship Program of the Kampus Merdeka-Merdeka Belajar Policy among Students

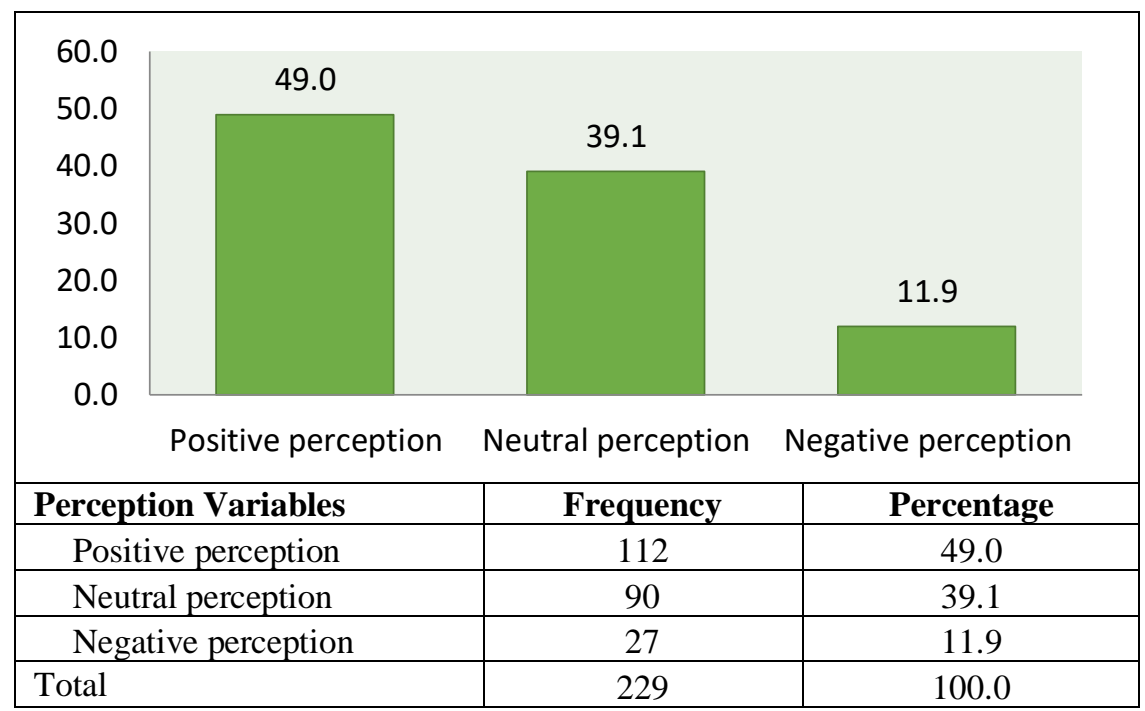

Figure 2. Summary Scores of Perception Variables

Figure 2 shows the summary scores of students' perceptions about the off-campus internship program of the Kampus Merdeka-Merdeka Belajar policy of the Ministry of Education and Culture of Indonesia. The results show that the positive perception among students scored the highest at $49 \%$ compared to the other variables - neutral 39\%; negative $12 \%$. The percentage is below $50 \%$ which means it is not so significant. However, the negative perception about this program is very low which is only $12 \%$ compared to that of the positive one. So, based on this score, the students had a positive perception toward the offcampus internship program of the Kampus Merdeka-Merdeka Belajar policy. 
Optimism about Off-Campus Internship Program of the Kampus Merdeka-Merdeka Belajar Policy among Students

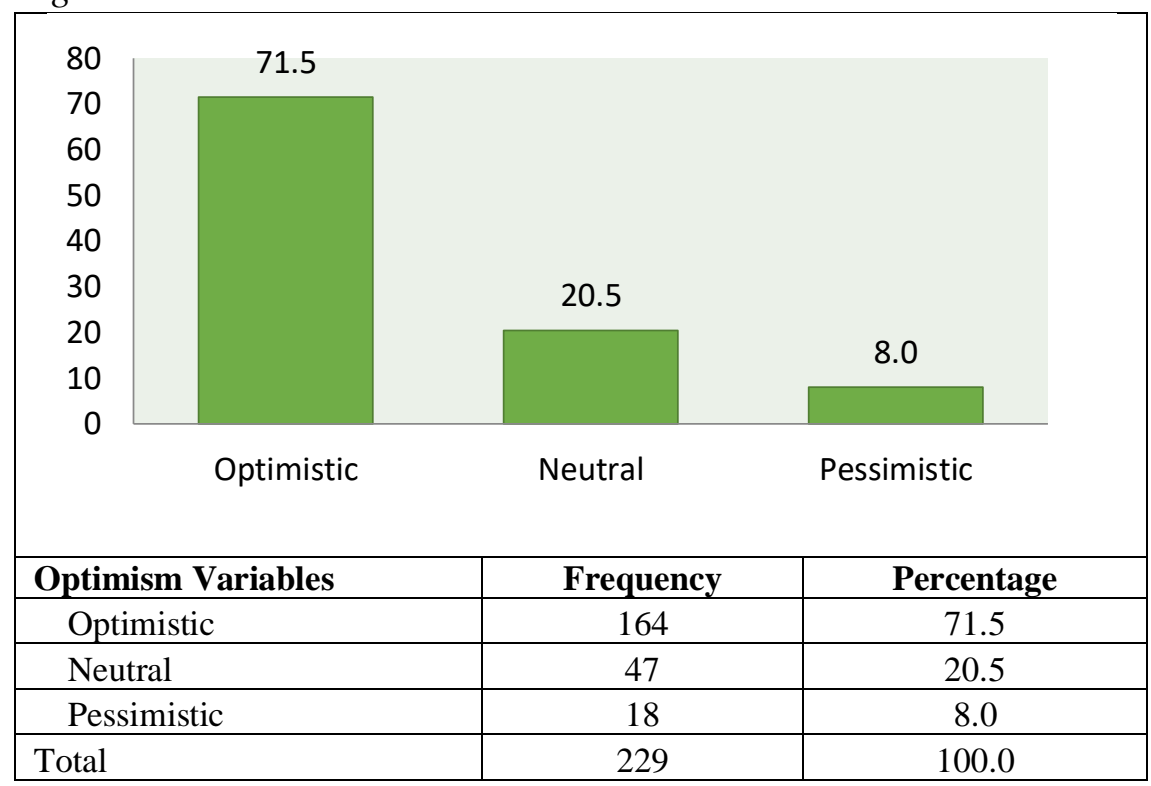

Figure 3. Summary of Average Scores of Optimism Variables

Figure 3 shows the summary average scores of students' optimism concerning the offcampus internship program of the Kampus Merdeka-Merdeka Belajar policy of the Ministry of Education and Culture of Indonesia. The scores show that the optimistic variable scored the highest at $71.5 \%$ compared to the neutral $(20.5 \%)$ and the negative ones $(8 \%)$. The percentage is more than $70 \%$ which means the number is very significant compared to those who have a pessimistic notion about this program which is only $8 \%$. So, based on this score, the students had a high level of optimism toward the effectiveness of the off-campus internship program of the Kampus Merdeka-Merdeka Belajar policy.

\section{CONCLUSION}

The results of the study reveal that for perception questions: (1) the majority of students perceived the off-campus internship program of Kampus Merdeka-Merdeka Belajar policy would be satisfying (61\%); (2) Most of the students had neutral opinion concerning whether this program would be overwhelming for them (47\%), while those who perceived that it would be vs. would not be (overwhelming) shared almost the same scores, respectively, 27\% vs. 26\%; (3) majority of students $(58 \%$ ) perceived that this program would not be a burden for them; (4) $49 \%$ of students disagreed with the claim that this program would only give benefit for the companies or industries, while a very small number of them perceived that it would $(9.2 \%)$. Thus, based on the summary scores of perception variables shown in Figure 2 (the Discussion section), it can be concluded that the students had a positive perception about the off-campus internship program of the Kampus Merdeka-Merdeka Belajar policy.

While for optimism questions, the results expose that: (1) the majority of students $(81 \%)$ had very high optimism that the internship program would improve their familiarity, understanding, or knowledge of the study; (2) the majority of the students (84\%) had very high optimism that the program would improve their skills and pre-working experiences; (3) a significant number of students had strong optimism (62\%) that the leadership of the Ministry of Education and Culture in the hands of new minister would hit the target to upgrade the quality of our national education; (4) $59 \%$ of students were optimistic that this program would be effective to reduce the skyrocketing number of unemployed undergraduates. Accordingly, 
based on the summary scores of optimism variables shown in Figure 3 (in the Discussion section), this study concludes that the students had a high level of optimism (71\%) concerning the effectiveness of off-campus internship program of the Kampus Merdeka-Merdeka Belajar policy administered by the Ministry of Education and Culture of the Republic of Indonesia.

\section{REFERENCES}

Borgohain, S. 2016. Commercialization of Education system: A critical analysis. International Research Journal of Interdisciplinary \& Multidisciplinary Studies (IRJIMS). A Peer-Reviewed Monthly Research Journal ISSN: 2394-7969 (Online), ISSN: 2394-7950 (Print) Volume-I, Issue-XII, January 2016, Page No. 71-76 Published by: Scholar Publications, Karimganj, Assam, India, 788711 Website: http://www.irjims.com.

Dasein, B.M. (2018). Freedom To Learn For The 21st Century (Education As If People Mattered). A Dissertation. University of Birmingham. https://etheses.bham.ac.uk/id/eprint/8553/1/Dasein18EdD.pdf

Dewantara, K.H. (2004). Bagian Pertama: Pendidikan. Cet: 3 Yogyakarta: MLPTS. . (2009). Menuju Manusia Merdeka, Yogyakarta: Leutika.

Gray, P. (2011). The Roles of Play and Curiosity as Foundations. "Learning Requires Freedom: Introduction to a New Blog about Play, Curiosity, and Education". Psychology Today.com. https://www.psychologytoday.com/us/blog/freedom-learn.

Hemlata \& L.K. Sharma. 2019. Commercialization fo Education. International Journal of Recent Technology and Engineering (IJRTE). ISSN: 2277-3878,Volume-8, Issue 1C2, May 2019.

Kemendikbud. (2020, December 11). Empat Pokok Kebijakan Merdeka Belajar. Retrieved January 10, 2020, from https://www.kemdikbud.go.id/main/blog/2019/12/empat-pokokkebijakan-merdeka-belajar.

Kemendikbud. (2020, January 24). Mendikbud Luncurkan Empat Kebijakan Merdeka Belajar: Kampus Merdeka. Retrieved January 31, 2020, from: https://www.kemdikbud.go.id/main/blog/2020/01/mendikbud-luncurkan-empatkebijakan-merdeka-belajar-kampus-merdeka.

Kemendikbud. (2020, January 24). Kebijakan Merdeka Belajar 2: “Kampus Merdeka". Retrieved January 31, 2020, from: https://www.kemdikbud.go.id/main/blog/2020/01/kebijakan-merdeka-belajar--kampusmerdeka.

Kemendikbud. (2020, February). Kampus Merdeka oleh Prof Dr. Nizam, M.Sc. Retrieved February 27, 2020, from: http://lldikti3.ristekdikti.go.id/v6/wpcontent/uploads/2020/02/Kampus-Merdeka-oleh-Prof.-Dr.-Nizam-M.Sc_.pdf.

Media Indonesia. (2020, June 26). Merdeka Belajar Menuju Pendidikan Ideal. Retrieved June 27, 2020, from: https://mediaindonesia.com/read/detail/278427-merdeka-belajarmenuju-pendidikan-ideal.

Mujito, W.E. (2014). Konsep Belajar Menurut Ki Hadjar Dewantara dan Relevansinya dengan Pendidikan Agama Islam. Jurnal Pendidikan Agama Islam. Vol. XI, No. 1, Juni 2014.

Muslih. (2014). Analisis Efektifitas Program Magang untuk Sinkronisasi Link and Match Perguruan Tinggi dengan Dunia Industri: Studi Terhadap Program Magang pada Fakultas Ekonomi Prodi Manajemen Universitas Muhammadiyah Sumatera Utara. Jurnal Manajemen dan Bisnis. Vol. 14 No. 01 April 2014. 
Mustaghfiroh, S. (2020). Konsep "Merdeka Belajar" Perspektif Aliran Progresivisme John Dewey. Jurnal Studi Guru dan Pembelajaran, Vol. 3, No. 1, March 2020.

Nofiani, M. \& Julianto, T. (2018). Efektivitas Pelaksanaan Program Magang Pembelajaran terhadap Kemampuan TPACK (Technological Pedagogical Content Knowledge) Mahasiswa Calon Guru Biologi FKIP Universitas Muhammadiyah Purwokerto. Proceeding Biology Education Conference. Volume 15, Nomor 1 Halaman 577-582 p-ISSN:2528-5742. Oktober 2018.

Nugroho, L.A.\& Purwanta, H. (2020). Perspektif Filsafat Rekonstruksionisme dalam Penyusunan Kurikulum. Jurnal Historika. Vol. 23 No. 1 April 2020.

Osman, A.A. (2013, January). Freedom in Teaching and Learning. International Journal of Humanities and Social Science. Vol. 3 No. 2, Special Issue - January 2013.

Prabowo, H. (2020, January 26). Pro dan Kontra atas Kebijakan Kampus Merdeka Nadiem. Retrieved January, 30 2020, from: https://tirto.id/pro-dan-kontra-atas-kebijakankampus-merdeka-nadiem-evs2.

Rasional Media. (2020, February 28). Kampus Merdeka ala Nadiem Menuai Kritik. Retrieved March 02, 2020, from: https://rasionalmedia.id/post/kampus-merdeka-ala-nadiemmenuai-kritik.

Republika (2020, March, 05). Kemendikbud: Magang dan KKN di Kampus Merdeka Bisa Setahun. Retrieved March 15, 2020, from: https://republika.co.id/berita/q6pzwx428/kemendikbud-magang-dan-kkn-di-kampusmerdeka-bisa-setahun.

Richards, J.I., Wartella, A., Morton, C., Thompson, L. 1988. The Growing Commercialization of Schools: Issues and Practices. The Annals of the American Academy. pp. 148-163. ANNALS, AAPSS, 557, May 1988. Downloaded from ann.sagepub.com by guest on March 13, 2015.

Tempo. (2020, January 26). UGM Supports Nadiem Makarim's Independent Campus Policy: Rector. Retrieved February 01, 2020 from: https://en.tempo.co/read/1299779/ugmsupports-nadiem-makarims-independent-campus-policy-rector.

Tempo. (2020, January 26). UI Hingga UGM Respons Positif Kampus Merdeka Nadiem Makarim. $\quad$ Retrieved $\quad$ February $01, \quad 2020$ from: https://nasional.tempo.co/read/1299809/ui-hingga-ugm-respons-positif-kampusmerdeka-nadiem-makarim.

UNICEF. (2007). A Human Rights-Based Approach to Education: A framework for the realization of children's right to education and rights within education. United Nations Educational, Scientific and Cultural Organization. New York, NY 10017, USA. pubdoc@unicef.org.www.unicef.org. ISBN: 978-92-806-4188-2.

Wijaya, N.I. (2019) Efektifitas Program Magang Mahasiswa Bersertifikasi (PMMB) Dalam Mendukung Tujuan Mata Kuliah Kerja Praktik (KP) di Universitas Hang Tuah. Proceeding Indonesia Career Center Network Summit IV. e-ISSN : 2715-5544 dan pISSN: 2686-6560 Samarinda, 17-18 Oktober 2019 82.nirmalasari@hangtuah.ac.id

Wirawan, P.E., Antara, I.M., Prasiasa, D.P.O. (2017). Motivasi Magang Kerja Mahasiswa Pariwisata Bali di Amerika Serikat. Jumpa. Volume 3 Nomor 2, Januari 2017. 